\title{
The Sustainability of Non-renewable Resources Use at Regional Level: A Case Study on Allocation of Oil Royalties
}

\author{
Mauro Viccaro, Benedetto Rocchi, Mario Cozzi, and Severino Romano
}

\begin{abstract}
The aim of this work was to assess the socioeconomic impact derived from the oil royalty allocation on regional development, using a multi-sector model based on a Social Accounting Matrix (SAM), appropriately implemented for Basilicata region (Italy), the typical case of a region lagging behind in a developed economy. Our focus was on how political decisions have influenced the economic development of the region and how a different set of choices can be more effective in transforming public receipts into long-term benefits. Results show clearly that in the past the allocation of oil royalties to the regional Government (as a whole 990 million euros) generated a much lower impact than expected, in terms of economic growth and employment. Given the structure of the regional economy, much of the impact of investments and running expenses financed by royalties has maybe been lost outside the regional boundaries. A greater effect on income and employment will not be possible unless resources are redirected towards greater competitiveness of the regional economic system. Better balancing the use of royalties between social expenditure and production investments would probably be the first step towards a strategy of sustainable development of the regional economy.
\end{abstract}

\section{Introduction}

The countries and regions that use a new natural resource, such as an oil deposit, usually see an increase in their financial resources due to the benefits (both direct and indirect) deriving from oil drilling. Their ability in managing these additional resources in a sustainable way influences the future of their entire economy. According to the big push theory (Rosenstein-Rodan 1943; Hirschman 1958), the new source of income should lead to increase public investments, promote growth

M. Viccaro • B. Rocchi • M. Cozzi $(\bowtie) \cdot$ S. Romano

School of Agricultural Sciences, Forestry, Food and Environment - SAFE, University of

Basilicata, viale dell'Ateneo Lucano 10, 85100 Potenza, Italy

e-mail: mauro.viccaro@unibas.it; mario.cozzi@unibas.it 
and result in long-term economic development. However, empirical evidence reveals a negative correlation between the abundance of resources and economic growth, known as natural resource curse (Sachs and Warner 2001). Different studies, concerning not only economic but also political and social aspects, have provided different possible explanations of this phenomenon (Larsen 2006; Torvik 2009; Van der Ploeg 2011). A preliminary economic interpretation of the negative relation between the dependence on the exploitation of natural resources and economic growth is known as the Dutch disease (Torvik 2009; Van der Ploeg 2011). This expression refers to the decline of production activities observed in the Netherlands after a large natural gas deposit was discovered at the end of the 1950s. According to this model, the big inflows of foreign capitals resulting from the export of resources overvalue the actual exchange rate, thus reducing capital and labour for agricultural and manufacturing activities. As a consequence, production costs increase, while the competitiveness and exports of the sectors unrelated to the resource decrease, with a depressing effect on the growth of the whole economy. Two more aspects seem to be the cause of the natural resource curse: (1) the implementation of non-sustainable macroeconomic policies by Governments, due to the abundance of resources (Atkinsons and Hamilton 2003), and (2) the intrinsic volatility of the international market of non-renewable resources (Van der Ploeg 2011).

The planning and implementation of effective policies to contrast this process is a challenge for Governments, not an easy one, especially in developing countries; typical examples are Chad and Brazil where, despite the huge financial resources derived from oil royalties, the living standard of populations has not improved accordingly (Keenan 2005; Pegg 2005; Caselli and Michaels 2013).

Different studies suggest that the appropriate policy to prevent the curse in developing countries is based on the allocation of the financial resources derived from oil-related activities towards policies aimed at promoting productivity, competitiveness and well-being improvement (Levy 2006; Breisenger et al. 2010; Rocchi et al. 2015).

It is worth noting that developing countries are not the unique countries involved by this curse, which may also influence, to a different extent, the regions lagging behind in developed economies that start to exploit a new natural resource, such as oil fields (Rocchi et al. 2015). The negative impact in these cases seems to be mostly due to the following: (1) the opening of the regional economy would result in the loss of most effects derived from the expenditure of royalties out of the regional boundaries; (2) the sudden increase in the export base may conceal the lack of competitiveness of the regional non-oil exporting sectors in relation to the rest of the country, reducing the investments required to improve their competitiveness; (3) part of oil royalties are used in short-term local redistribution policies aimed at reducing the negative effect of the regional economic gap (including unemployment and poverty), but are ineffective in improving the competitiveness of the regional system in the long run. Lastly, if the allocation of these financial resources is not implemented with due appropriateness and transparency, the entailed risks are bribery or rent-seeking behaviours. 
To prevent these adverse effects and favour the highest possible outfalls on the areas involved by financial investments based on the use of royalties, the priority for decision-makers is to better focus on the strategic objectives to promote long-term sustainable socioeconomic development, while compensating for the deployment in environmental assets resulting from the exploitation of a non-renewable resource.

The possibility of setting out regional policies, assessing the impact on the main socioeconomic indicators at the local level and monitoring the effectiveness over time is largely dependent on the availability of an adequate territorial information system that should be complete, relevant and coherent both internally and with the national framework (Carbonaro et al. 2001). Different authors (Stone 1961; Seers 1970, 1972) maintain that the most suitable statistical tool, in terms of information bases and economic model, is the Social Accounting Matrix (SAM). As a matter of fact, it has a regional dimension enabling to analyse different economic and fiscal policies within the same country, notably when large internal differences coexist (Thorbecke 1985).

The aim of this work is to assess the socioeconomic impact derived from the allocation of oil royalties on the regional development, using a multi-sector model based on a two-region SAM, specially tailored to Basilicata region, a typical example of a region lagging behind in a developed economy. After describingvia different macroeconomic indicators - the regional economic system (see Sect. 2.1) and the methodology applied to perform the impact analysis based on SAM multipliers (see Sect. 2.2), the allocation of oil royalties is examined from 1997 to 2013, making it possible to implement the model (see Sect. 2.2.1). Results are shown in Sect. 3, and conclusive remarks (see Sect. 4) close the paper.

\section{Materials and Methods}

\subsection{Case Study: Basilicata Region}

The Basilicata region is the typical case of a region lagging behind the rest of the national economy.

Despite the presence - in its territory — of the largest onshore oil field in Europe, Basilicata's economy shows strong difficulties compared with the rest of the country, with a poverty index more than double the national average (Fig. 1) (Istat 2014).

When oilfields were discovered in the Agri valley (in the southwestern part of the region) in the early 1990s, they were considered as an important opportunity for the regional economy. The oil regional industry currently produces about 16,137 tons/day of crude oil: in 2013 , the production was about 5.48 million tons, i.e. $9.3 \%$ of the gross national domestic consumption and about $71.7 \%$ of Italy's total crude oil production (Ministero dello Sviluppo Economico 2014). There are indeed good 


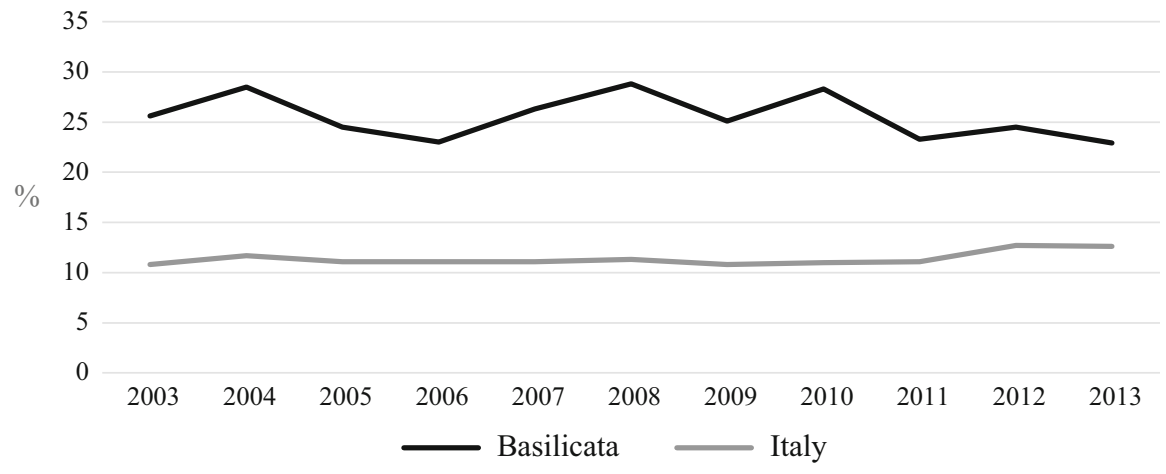

Fig. 1 Relative poverty index

opportunities for the regional economic development (in addition to the direct impact on employment) in the form of royalties. Under the agreement between the State and oil drilling companies, above a given output threshold, the companies must give $7 \%$ of their earnings to the regions in the form of royalties and an additional $3 \%$ for safety and environmental monitoring (Ministero dello Sviluppo Economico 2014). This has meant that between the start of drilling in 1997 and the end of 2013, the regional balance has matured over 990 million euros earnings from oil.

Moreover, a recent national regulation ( $\mathrm{N}^{\circ}$ 99/2009) allocates an additional $3 \%$ of earnings to the households living in Basilicata as vouchers to purchase fuel (fuel card).

Surprisingly, oil earnings have not had a great impact on the local economy, despite the huge quantity of additional financial resources channelled into regional development policies. Figure 2 shows that the regional GDP grew quite steadily till 2008, when it experienced a decline-partly due to the overall economic recession-resulting in a decrease of employment to 195,000 labour units recorded in 2012. In accordance with the national trend, the unemployment rate has increased starting from 2007 till $16 \%$ in 2013 (Istat 2014).

This results in a loss of competitiveness, in terms of labour productivity (Fig. 3).

While the average productivity of the other southern Italy regions has slightly decreased, between 1995 and 2009, the Basilicata region has seen a considerable decline: although the regional employment till 2003 has grown more rapidly than in the neighbouring regions, this has not resulted in a substantial increase in terms of productivity.

It is evident that oil exploitation has not generated the expected benefits according to the big push theory, due maybe to all of the causes that contribute to explain the so-called natural resource curse (Van der Ploeg 2011).

It is thus crucial to understand how resources are allocated and to assess their impact on the socioeconomic system for trying to provide an explanation of the current situation. 


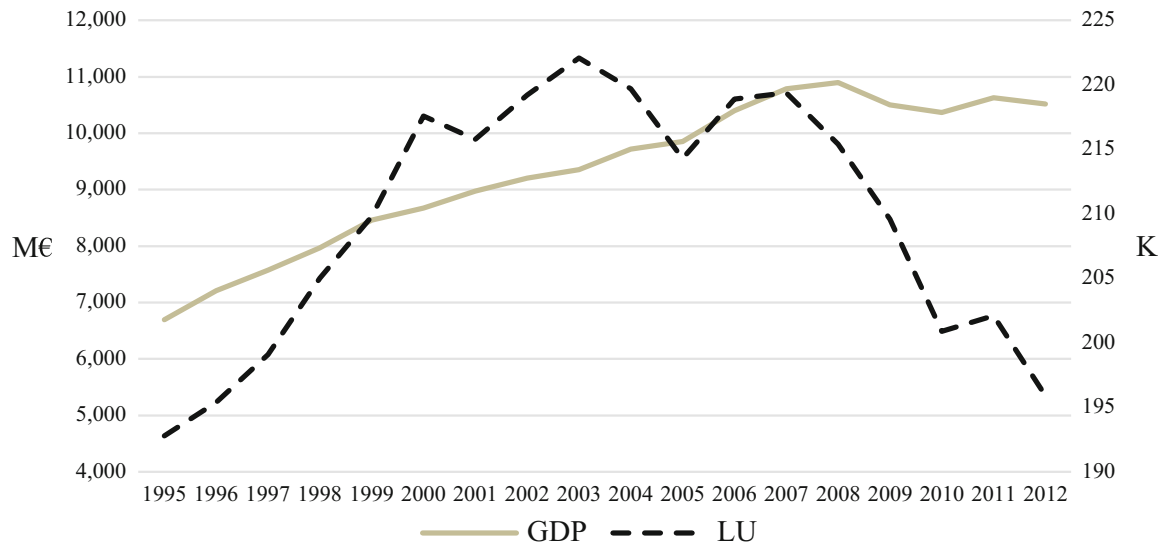

Fig. 2 GDP (M€) and labour unit (K)

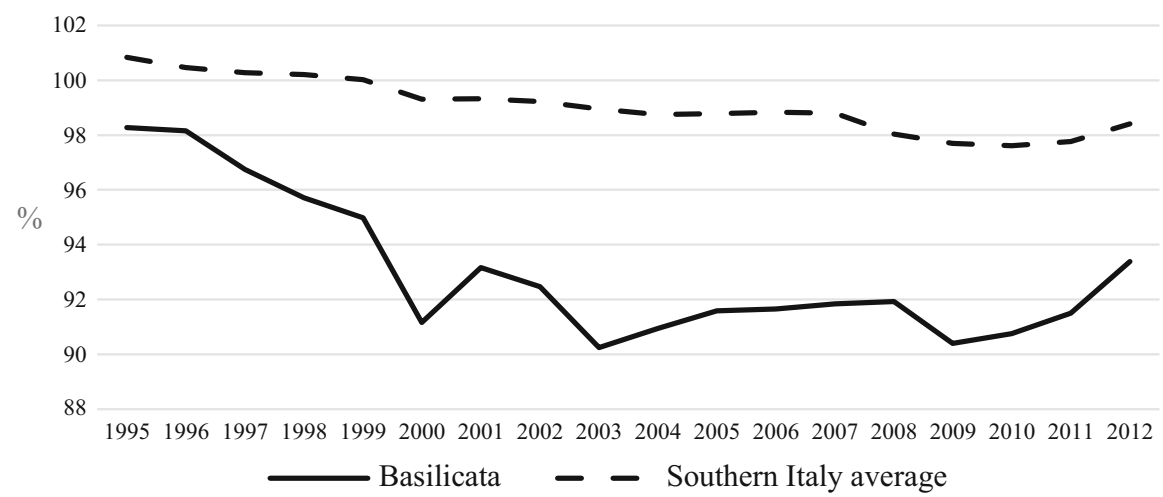

Fig. 3 GDP per labour unit-ratio between different areas

\subsection{SAM: A Two-Region Model}

A model based on SAM has been used to assess the impact of the allocation of the oil royalties earned by Basilicata region since the start of drilling till now. The SAM (Pyatt 1991a, b, 1994a, b, 1999; Pyatt and Round 1977, 1985) is a two-entry matrix that records the flows occurring between all actors of an economic system, in a given place and for a given time period (usually 1 year). Each raw/column pair represents, respectively, the inflows and outflows of a given account, so that by definition the matrix is balanced (the row totals equal the column totals). It may be considered as an expansion or a generalisation of Leontief's input-output table (1936). While in the latter emphasis is laid on the production system, in the SAM the perspective is larger. The simultaneous representation of the accounts of production activities, production factors, institutions (households, businesses and 
public administration), capital formation and exchanges with the rest of the world makes it possible to follow the formation of value added and its distribution and redistribution in the form of income to the institutions.

The utilisation of SAMs in the analysis of development is by now a wellestablished branch of the economic literature (Stone 1961; Pyatt and Round 1977, 1985; Pyatt 1991a, b, 1994a, b, 1999; Round 2003; Miller and Blair 2009). Applications refer both to developed and developing economies, because it is not only an important tool to improve the consistency of national accounting estimates (United Nations et al. 1993) but also the first step for the calibration of impact simulation multi-sector models, both linear and computable general equilibrium ones (Pyatt 1988). Through the implementation of a linear model based on the calculation of multipliers (Miller and Blair 2009), it is possible to calculate the impact that variables have on the economic system; endogenous accounts normally include the institutional sectors of households and firms; the unique accounts that are considered, either alternatively or simultaneously, exogenous to the model are those of Government, of the rest of the world and of the capital account. Deciding which and how many of these three accounts are exogenous means establishing the "closing rule" of the model based on the SAM (Miller and Blair 2009).

The SAM used in this study is a two-region matrix, referred to 2010, in which the existing flows between Basilicata region and the rest of Italy are represented with a high level of detail. The structure of the matrix includes 301 accounts, subdivided into 37 production activities, 54 production factors and 3 institutions (households, businesses and Government). The household sector is subdivided by income deciles into ten groups, whereas the Government is distinguished as local and central. There are of course also the accounts entitled to the capital formation and to the rest of the world.

The advantage of a two-region model lies in the possibility of considering the rest of Italy as being endogenous to the model; this makes it possible to break down impacts and estimate not only the total but also the intraregional and interregional ones (spillovers and feedbacks).

In the present study, for the analysis of the impacts derived from the use of oil royalties considered as exogenous shocks to the regional economy, a static analysis has been carried out, considering a closure of the model with respect to the Government, capital formation and rest of the world: the estimated multipliers take thus the value of Leontevian-Keynesian multipliers.

The structure of the matrix of accounting coefficients of the two-region model is shown below (Miller and Blair 2009):

$$
A=\left[\begin{array}{ll}
A^{\mathrm{rr}} & A^{\mathrm{rs}} \\
A^{\mathrm{sr}} & A^{\mathrm{ss}}
\end{array}\right]
$$

where $\mathrm{r}=$ Basilicata region and $\mathrm{s}=$ rest of Italy.

By solving the linear system $x=A x+f$ (where $x$ is the vector of totals of endogenous accounts and $f$ is the vector of exogenous account flows) for $x$, you have 


$$
x=(I-A)^{-1} f
$$

where $M=(I-A)^{-1}$ is the matrix of SAM multipliers.

Each coefficient $m_{i j}$ quantifies the total increase for each account $i$ derived from a unit exogenous shock on the account $j$.

If the matrix of multipliers $M$ enables the estimate of the total impact, the breakdown of the matrix of accounting coefficients $A$ into intraregional $\left[\begin{array}{cc}A^{\mathrm{rr}} & 0 \\ 0 & A^{\mathrm{ss}}\end{array}\right]$ and interregional elements $\left[\begin{array}{cc}0 & A^{\mathrm{rs}} \\ A^{\mathrm{sr}} & 0\end{array}\right]$ enables to estimate (Round 1985, 2001; Dietzenbacher 2002; Miller and Blair 2009) the following:

$$
\text { Intraregional effects : } M_{1}=(I-\tilde{A})^{-1}
$$

where $\widetilde{A}=\left[\begin{array}{cc}A^{\mathrm{rr}} & 0 \\ 0 & A^{\mathrm{ss}}\end{array}\right]$.

Interregional spillover effects : $M_{2}=I+A^{*}$

where $A^{*}=(I-\tilde{A})^{-1}(A-\tilde{A})$.

$$
\text { Interregional feedback effects : } M_{3}=\left[I-\left(A^{*}\right)^{2}\right]^{-1}
$$

Let us consider the intraregional submatrix $A^{\mathrm{rr}}$ and the blocks constituting it:

$$
A^{\mathrm{rr}}=\left[\begin{array}{ccc}
B & 0 & C \\
V & 0 & 0 \\
0 & Y & H
\end{array}\right]
$$

where $B$ is the matrix of interindustry technical coefficients, $C$ is the matrix of endogenous final expenditure coefficients, $V$ is the matrix of endogenous value added factor shares, $Y$ is the matrix of endogenous coefficients distributing income to institutions and $H$ is the matrix of endogenous coefficients for income redistribution among institutions. The intraregional effect of impacts may in turn be broken down as follows (Miller and Blair 2009):

$$
\text { Regional direct effect }: M_{1}^{\mathrm{rr}}=(I-Q)^{-1}
$$

where $Q=\left[\begin{array}{ccc}B & 0 & 0 \\ 0 & 0 & 0 \\ 0 & 0 & H\end{array}\right]$ 
where $T=(I-Q)^{-1} R, R=\left[\begin{array}{ccc}0 & 0 & C \\ V & 0 & 0 \\ 0 & Y & 0\end{array}\right]$.

$$
\text { Regional feedback effect }: M_{3}^{\mathrm{rr}}=\left(I-T^{2}\right)^{-1}
$$

Once the multipliers required for the analysis are calculated and the vector of shocks $d f$ defined, it will be possible to define the vector of impacts $d x$ as follows:

$$
d x=M d f
$$

In the present study, the vector of shocks is made up of the current and capital expenditures of the oil royalties according to different scenarios.

\subsubsection{The Vectors of Exogenous Shocks: Allocation of Oil Royalties}

The available information on the allocation (or distribution) of royalty earnings among different uses is summarised in Table 1, where the total amount is disaggregated by year and action.

For most receipts, it has been impossible to allocate expenses by specific political actions. About three quarters of total expenditure (over 723 million euros) has been just used to fund running expenses of Basilicata region (itemised as other actions).

The remainder has been shared among various initiatives mostly designed towards the mitigation and compensation of adverse effects derived from the oil mining industry. The environmental issues involved in the exploitation of the major inshore oil source in Europe are obviously very important. The location of oil fields influences high nature value areas, which have a considerable potential for the development of tourism and agricultural activities. Moreover, the mining plants and the distribution pipelines of the existing processing plants on the coast concern an area that stores the major water resource for southern Italy. For this reason, the regional Government has decided to mitigate the possible negative impacts by setting up a system for the monitoring and compensation of the areas directly affected by oil drilling operations.

One of the most important actions funded by royalties is the Piano Operativo Val d'Agri (POV), an expenditure operating plan aimed at promoting economic development and the improvement of life quality in the area neighbouring the oil fields. The POV is structured into four pillars related to the enhancement of local resources, the improvement of infrastructures, the improvement of life quality and the improvement of the local production supporting systems. The POV includes both current expenditures and investments. 
Table 1 Allocation of royalties by action (M€)

\begin{tabular}{|c|c|c|c|c|c|c|}
\hline Year & POV & $\begin{array}{l}\text { Other } \\
\text { actions }\end{array}$ & $\begin{array}{l}\text { Natural gas } \\
\text { distribution } \\
\text { network }\end{array}$ & $\begin{array}{l}\text { Environmental } \\
\text { monitoring }\end{array}$ & $\begin{array}{l}\text { Environmental } \\
\text { compensation }\end{array}$ & Total \\
\hline 1997 & 0 & 0.43 & 0 & 0 & 0 & 0.43 \\
\hline 1998 & 0 & 2.25 & 0 & 0 & 0 & 2.25 \\
\hline 1999 & 0 & 1.24 & 0 & 0 & 0 & 1.24 \\
\hline 2000 & 0 & 3.17 & 0 & 5.01 & 11.02 & 19.20 \\
\hline 2001 & 0 & 8.04 & 1.03 & 0 & 5.58 & 14.65 \\
\hline 2002 & 0 & 10.04 & 0 & 0 & 0 & 10.04 \\
\hline 2003 & 0 & 24.05 & 0 & 0 & 5.60 & 29.65 \\
\hline 2004 & 4.89 & 30.31 & 7.00 & 0 & 5.61 & 47.81 \\
\hline 2005 & 6.23 & 32.80 & 0 & 0 & 5.62 & 44.63 \\
\hline 2006 & 17.26 & 61.84 & 0 & 0 & 5.68 & 84.78 \\
\hline 2007 & 23.98 & 72.57 & 17.79 & 0 & 5.67 & 120.02 \\
\hline 2008 & 31.39 & 71.30 & 0 & 0 & 0 & 102.69 \\
\hline 2009 & 22.10 & 79.47 & 0 & 0 & 3.10 & 104.67 \\
\hline 2010 & 26.10 & 28.15 & 0 & 0 & 0 & 54.25 \\
\hline 2011 & 25.88 & 59.21 & 0 & 0 & 0 & 85.09 \\
\hline 2012 & 12.04 & 111.58 & 0 & 0 & 0 & 123.62 \\
\hline 2013 & 17.82 & 127.49 & 0 & 0 & 0 & 145.31 \\
\hline Total & 187.67 & 723.94 & 25.82 & 5.01 & 47.88 & 990.31 \\
\hline
\end{tabular}

POV Piano Operativo Val d'Agri

To calculate the total impact of the use of royalties in the time period under study, all these expenditure flows have been considered as an exogenous shock directed towards the regional economy and reclassified based on the disaggregation of accounts in the SAM. While in the case of allocation towards specific actions there have been no problems in identifying the accounts on which they are directed, the expenses concerning other actions, in the basic simulation, have been considered as an exogenous increase of the local public administration expenditure and have been distributed as inputs towards the endogenous accounts, based on the current expenditure coefficients of the regional administration included in the SAM.

Moreover, the analysis also takes into account the shares for the fuel card supplied so far. ${ }^{1}$ These shares have been considered as an exogenous increase in income of the households living in the region, according to a distribution based on what is declared by the Ministry of Economic Development (2014) (Table 2).

Since the envisaged uses refer to different years, the values have been converted into 2013 Euros (Istat 2014).

\footnotetext{
${ }^{1}$ The shares concerning the fuel card have been supplied starting from 2011; till now the two first supplies concern the shares allocated for 2009 and 2010.
} 
Table 2 Amounts concerning the supply of the fuel card

\begin{tabular}{l|l|l}
\hline Year & Amounts $(\mathrm{M} €)$ & $\mathrm{N}^{\circ}$ beneficiaries \\
\hline 2009 & 32.22 & 320,000 \\
\hline 2010 & 44.88 & 320,000 \\
\hline
\end{tabular}

Two ex post analyses of the impacts derived from the use of royalties were conducted:

1. Impact of the expenditure relating the use of royalties allocated in 2010, the reference year in the SAM construction (counterfactual analysis); this analysis also estimates the potential impact that could be generated from the granting of fuel vouchers for 2010.

2. Total impact derived from the total expenditure of royalties till now, based on their actual use.

Moreover, to provide helpful indications on the possible effects of an alternative use of the financial resources derived from mining, the four following simulations have been made that assume a different use of the shares allocated to other actions:

1. Increase in current consumption for public administration (scenario I)

2. Increase in the current consumption of public administration and in transfers to households (scenario II)

3. Funding of current activities of private enterprises (scenario III)

4. Funding of investments of private enterprises (scenario IV)

\section{Results}

On the basis of the counterfactual analysis for 2010 (Table 3), it resulted that part of the effect derived from the use of royalties occurs outside the regional boundaries: only about $50 \%$ of what has been utilised has entailed a direct impact in the region. The remaining uses have resulted in the growth of output, value added and income of households through moderate feedbacks from the rest of Italy.

As compared to the baseline scenario, the impact of royalties on the regional economy involves a $0.3 \%$ increase of output and value added and $0.2 \%$ rise in households' gross income (actual use). The lower impact observed on the income depends on the fact that the expenditure of royalties is mostly concentrated on the accounts allocated to the production and purchase of goods and services. If fuel vouchers had been supplied in 2010 (hypothetical use), this would have resulted in an additional $0.49 \%$ increase of households' income, with outfalls on the whole economy, leading to an additional $0.2 \%$ increase of the output and value added. This is due to a higher availability of households' income for the purchase of goods and services, especially outside the regional boundaries: above $70 \%$ of the output and value added generated in the region benefits the rest of Italy.

Through an analysis of the breakdown of impacts on the regional economy in 2010 (Table 4), it seems clear that a targeted programme like the POV results in a 


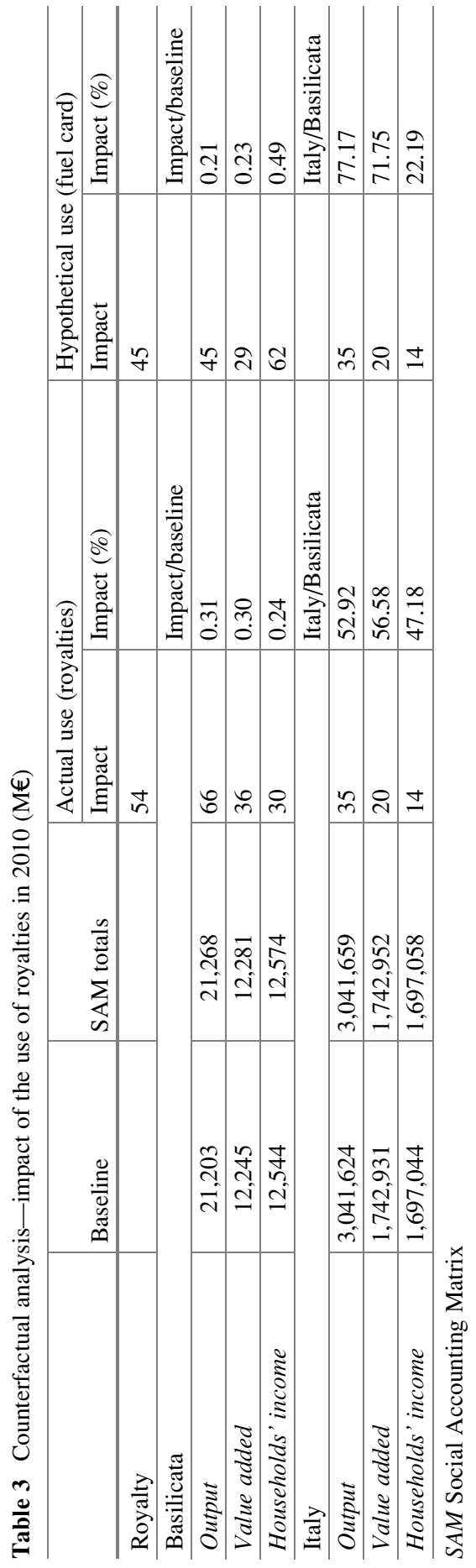


Table 4 Breakdown of impacts by allocation of 2010 royalties (M€)

\begin{tabular}{l|r|r|c}
\hline & Output & Value added & Households' income \\
\hline \multicolumn{5}{l}{ Direct impact } & 23.80 & 0.00 & 0.00 \\
\hline POV & 0.00 & 0.01 & 8.31 \\
\hline Other actions & 16.42 & 0.00 & 0.00 \\
\hline Indirect impact & 0.81 & 0.06 & 0.21 \\
\hline POV & 9.96 & 26.38 & 15.17 \\
\hline Other actions & 14.62 & 9.71 & 5.88 \\
\hline Induced impact & 65.61 & 36.16 & 29.57 \\
\hline POV & \multicolumn{5}{l}{} \\
\hline Other actions & 0.07 & 0.04 & 0.03 \\
\hline Regional total impact & 0.03 & 0.02 & 0.01 \\
\hline Interregional feedback & 65.70 & 36.22 & 29.60 \\
\hline POV & &
\end{tabular}

higher direct and indirect impact (through the production system) on the output, as compared to that related to the expenses incurred by other actions aimed to support the public administration expenditure. This expenditure has actually a direct impact on households' income leading to an induced impact on output and value added (multiplier effect) only through the increase in consumption.

If considering the total impact derived from the use of royalties since the beginning of drillings till now (Table 5), it results clearly-in this case as wellthat the POV seems much better in promoting growth and employment. Overall, royalties have generated an extra output of about 1 billion euros, 593 million euros of gross households' income and 10,258 total annual full-time labour units.

Table 5 shows that the ratio of generated output to the expenditure allocated to the POV is more than three times the one recorded for the other actions $(1.82 €$ vs. $0.55 €$ of additional output for each additional $€$ of expenditure). The POV has generated almost the same labour units using only $25 \%$ of the budget available for the other actions. These higher impacts are mainly due to the fact that a considerable portion of the POV expenditure is directed towards construction activities (both to improve infrastructures and to preserve the cultural heritage), a sector mainly based on local businesses.

As resulting from Fig. 4, the sectors that most bear on the output and employment include constructions, trade and private and public services. As for agriculture and fishery, despite their low multiplying effect on output (Table 6), their capacity to generate more employment on the produced output is double compared to the other sectors.

In general, however, most effects derived from the use of royalties have been lost by the regional economy. The typical opening of a regional economy is expressed by the ratio of the generated output to the total value of spent royalties: on average, only $0.88 €$ of additional output has been produced at the regional level for each $€$ 
Table 5 Impact of royalty uses by allocation type-2013 Euro $(\mathrm{M} €$ )

\begin{tabular}{l|l|l|l}
\hline \multirow{2}{*}{} & \multicolumn{3}{l}{ Allocation type } \\
\cline { 2 - 4 } & Total & Other actions & POV \\
\hline Royalties receipts & 1,166 & 786 & 203 \\
\hline Total impacts: & 1,027 & 432 & 370 \\
\hline Output & 593 & 274 & 194 \\
\hline Value added & 668 & 402 & 111 \\
\hline Households' income & 66,258 & 4,422 & 3,634 \\
\hline Labour unit $(n)$ & 10,25 & \\
\hline Average impacts: & \multicolumn{5}{|l}{} \\
\hline Output & 0.88 & 0.55 & 1.82 \\
\hline Value added & 0.51 & 0.35 & 0.95 \\
\hline Households' income & 0.57 & 0.51 & 0.55 \\
\hline Labour unit $(n)$ & 9 & 6 & 18 \\
\hline
\end{tabular}

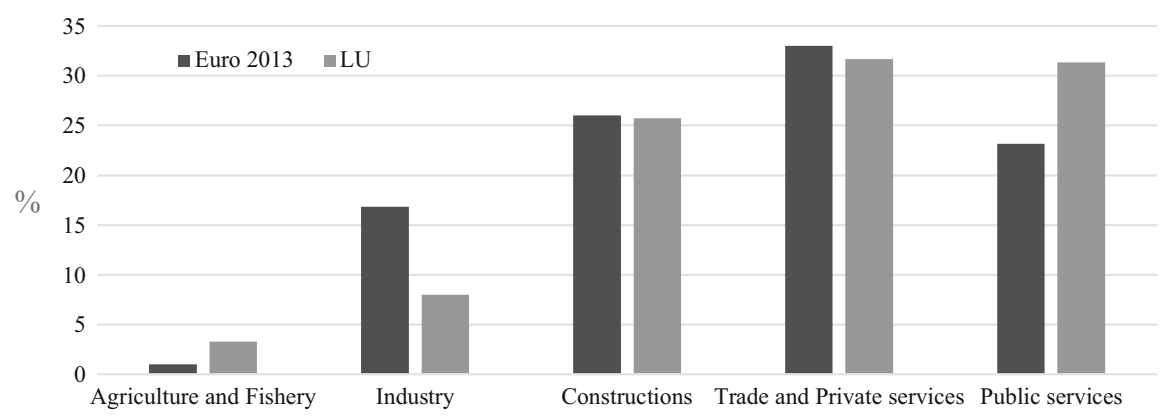

Fig. 4 Percent distribution of impacts on output and employment

Table 6 Sectoral output multipliers

\begin{tabular}{l|l}
\hline Sector & Output multipliers \\
\hline Agriculture and fishery & 1.56 \\
\hline Industry & 1.78 \\
\hline Constructions & 2.04 \\
\hline Trade & 1.82 \\
\hline Public services & 1.84 \\
\hline
\end{tabular}

spent. The mean incidence on the income is even smaller, with only $51 \%$ of expenditure converted into actual income earned by the households living in the region. The overall impact is thus moderate compared to the absolute value of the available budget, which has stabilised around 100 million euros/year (about $3 \%$ of the annual expenditure of public administration in Basilicata region). These results may only partly be assessed by static simulations. The use of supplemental financial resources derived from royalties has maybe played a fundamental role to tackle the regional economic decline. However, the allocation of these additional financial resources could be significantly improved also in the short run. 
Table 7 Simulations on the alternative use of royalties allocated to other actions (M€)

\begin{tabular}{|c|c|c|c|c|c|}
\hline & \multicolumn{5}{|c|}{ Allocation type } \\
\hline & Current use & Scenario I & Scenario II & Scenario III & Scenario IV \\
\hline Royalties receipts & 786 & & & & \\
\hline \multicolumn{6}{|l|}{ Total impacts: } \\
\hline Output & 432 & 1,072 & 869 & 792 & 1,049 \\
\hline Value added & 274 & 704 & 559 & 395 & 521 \\
\hline Households' income & 402 & 469 & 849 & 225 & 292 \\
\hline Labour unit $(n)$ & 4,422 & 11,012 & 8,982 & 7,344 & 9,454 \\
\hline \multicolumn{6}{|l|}{ Average impacts: } \\
\hline Output & 0.55 & 1.36 & 1.11 & 1.01 & 1.34 \\
\hline Value added & 0.35 & 0.90 & 0.71 & 0.50 & 0.66 \\
\hline Households' income & 0.51 & 0.60 & 1.08 & 0.29 & 0.37 \\
\hline Labour unit $(n)$ & 6 & 14 & 11 & 9 & 12 \\
\hline
\end{tabular}

We can deduce that a specific programme like the POV is a better solution in promoting economic growth in the short run; moreover, since this is a programme supporting investments in production activities, it has greater probabilities to improve the competitiveness of the regional economic system. An alternative use of the resources, allocated so far to the public administration expenditure, might further contribute to development.

Based on the simulations run (Table 7), it would seem that the uses of royalties directed to support only the public administration consumptions (scenario I), or the latter and the households' income (scenario II), are those that would generate greater impacts, in terms of output, value added, income and employment. These results are however controversial: the uses of part of oil royalties in supporting Government expenditure and in local redistribution policies are ineffective in improving the regional system competitiveness in the long run. This would have short-term effects mostly aimed to reduce the negative impact of the regional economic gap (such as unemployment and poverty).

An alternative solution would be provided by scenario IV, in which royalties are entirely spent to support the investments of private enterprises operating on the local scale, for the purpose of enhancing the competitiveness of the regional production system. The impact on the output and employment is comparable to that of scenario I. Although it presents, among the scenarios, one of the lowest impacts on the income in the short run $(0.37 €$ of income generated per $€$ of royalty spent), the strengthening of the regional production system competitiveness might lay the bases for sustainable economic development of the entire region in the long run. A strategy that is in line with the notion of sustainability of natural resources and involves a progressive replacement of the deployed natural assets (oil in this case) with the produced capital (Hamilton and Atkinson 2006). 


\section{Conclusion}

In this work, a multi-sector model based on a two-region SAM has been used to study the socioeconomic impact of the use of oil royalties on the economic system of Basilicata region.

To this purpose, it was necessary to carry out a counterfactual analysis to test the impact that the expenditure of royalties had in 2010 and an ex post analysis of royalty allocation since the beginning of drillings till now. Some simulations were performed to estimate the effect that might have been generated by a different use of the royalties actually utilised in funding the Government expenditure.

Results clearly show that in the past the allocation of oil royalties granted to the regional Government (as a whole 990 million euros) generated a much lower impact than expected, in terms of economic growth and employment. Given the structure of the regional economy, a large part of the impacts of investments and current expenses funded by royalties have been probably lost outside the regional boundaries. As a whole, the use of part of the royalties to support the regional Government expenditure has been less effective in promoting the regional economic growth compared to a targeted programme like the POV, aimed at supporting the areas where oil fields are found.

These results, together with the macroeconomic indicators that describe the economic system of the region (see Sect. 2.1), show clearly that Basilicata's economy is at risk for the natural resource curse. The same opacity in the distribution of royalties is a symptom of a potentially distorted policy and of the ineffective use of a considerable amount of additional financial resources. Detailed information about the use of royalties was actually available only for a quarter of the earnings received by Basilicata region between 1997 and 2013.

The additional financial resources derived from the exploitation of oil fields over the last few years have undoubtedly played a role to mitigate the impacts of the overall macroeconomic crisis. This use is understandable in a region, like Basilicata, that has an economic gap. However, the absence of a clear strategy targeted to increase the regional economic system competitiveness might, paradoxically, result in a deterioration of the relative position of Basilicata within the national economy. The exploitation of non-renewable natural resources could also crowd out the other production activities. Simulations show that even expenditure programmes directed to implement investments could favour economic growth in the short run, without jeopardising the regional system competitiveness prospects. Better balancing in the allocation of royalties between social expenditure and production investments would probably constitute the first step towards a sustainable development strategy of the regional economy. 
Open Access This chapter is distributed under the terms of the Creative Commons Attribution Noncommercial License, which permits any noncommercial use, distribution, and reproduction in any medium, provided the original author(s) and source are credited.

\section{References}

Atkinsons G, Hamilton K (2003) Savings, growth and the resource curse hypothesis. World Dev 31(11):1793-1807

Breisenger C, Diao X, Wiebelt S, Wiebelt M (2010) Managing future oil revenues in Ghana: an assessment of alternative allocation options. Afr Dev Rev 22(2):303-315

Carbonaro G, Tenna F, Roberto Z (2001) I conti economici regionali: alcune possibili riflessioni. Rapporto di ricerca 01.04. Commissione per la garanzia dell'informazione statistica, Presidenza del Consiglio dei Ministri

Caselli F, Michaels G (2013) Do oil windfalls improve living standards? Evidence from Brazil. Am Econ J Appl Econ 5(1):208-238

Dietzenbacher E (2002) Interregional multipliers: looking backward, looking forward. Reg Stud 36:125-136

Hamilton K, Atkinson G (2006) Wealth, welfare and sustainability. Advances in measuring sustainable development. Edward Elgar, Cheltenham

Hirschman AO (1958) The strategy of economic development, vol 58. Yale University Press, New Haven

ISTAT (2014) I.stat: il tuo accesso diretto alla statistica italiana. http://dati.istat.it/Index.aspx. Accessed 27 Nov 2014

Keenan J (2005) Chad-Cameroon oil pipeline: world band and ExxonMobil in 'Last Chance Saloon'. Rev Afr Polit Econ 104(5):395-477

Larsen R (2006) Escaping the resource curse and the Dutch disease? When and why Norway caught up and forged ahead of its neighbours. Am J Econ Sociol 65(3):605-640

Leontief W (1936) Quantitative input and output relations in the economic system of the United States. Rev Econ Stat 18:105-125

Levy S (2006) Public investment to reverse the Dutch disease: the case of Chad. In: IFPRI development strategy and governance division discussion papers, No. 35. http://www.ifpri. org/sites/default/files/publications/dsgdp35.pdf. Accessed 8 Sept 2014

Miller RE, Blair PD (2009) Input-output analysis, foundations and extensions. Cambridge University Press, New York

Ministero dello sviluppo economico (2014) Direzione generale per le risorse minerarie ed energetiche. http://unmig.sviluppoeconomico.gov.it/home.asp. Accessed 27 Nov 2014

Pegg S (2005) Can policy intervention beat the resource curse? Evidence from the ChadCameroon pipeline project. Afr Aff 105(418):1-25

Pyatt G (1988) A SAM approach to modelling. J Policy Model 10(3):327-352

Pyatt G (1991a) Fundamentals of social accounting. Econ Syst Res 3:315-341

Pyatt G (1991b) SAMs, the SNA and national accounting capabilities. Rev Income Wealth 37:179-199

Pyatt G (1994a) Modelling commodity balances: part I. Econ Syst Res 6:5-20

Pyatt G (1994b) Modelling commodity balances: part II. Econ Syst Res 6:123-134

Pyatt G (1999) Some Relationships between T-accounts, input-output tables and social accounting matrices. Econ Syst Res 11:365-387

Pyatt G, Round JI (1977) Social accounting matrices for development planning. Rev Income Wealth 23:339-364

Pyatt G, Round JI (eds) (1985) Social accounting matrices: a basis for planning. The World Bank, Washington, DC 
Rocchi B, Landi C, Stefani G, Romano S, Cozzi M (2015) Escaping the resource curse in regional development: a case study on the allocation of oil royalties. Int J Sustain Dev 18 (1/2):115-138

Rosenstein-Rodan PN (1943) Problems of industrialisation of eastern and south-eastern Europe. Econ J 53:202-211

Round JI (1985) Decomposing multipliers for economic systems involving regional and world trade. Econ J 95:383-399

Round JI (2001) Feedback effects in interregional input-output models: what have we learned? In: Lahr ML, Dietzenbacher E (eds) Input-output analysis: frontiers and extensions. Palgrave, New York, pp 54-70

Round JI (2003) Constructing SAMs for development policy analysis: lessons learned and challenges ahead. Econ Syst Res 15(2):161-183

Sachs JD, Warner AM (2001) The curse of natural resources. Eur Econ Rev 45(4-6):827-838

Seers D (1970) New approaches suggested by the Colombia employment programme. ILO'70: Int Labour Rev 102:380

Seers D (1972) New light on structural unemployment: lessons of a mission to Ceylon. ILO'72: Int Labour Rev 105:100

Stone R (1961) Social account at the regional level. In: Isard W, Cumberland JH (eds) Regional economic planning: techniques of analysis for less developed areas. OECD, Paris

Thorbecke E (1985) The social accounting matrix and consistency-type planning models. In: Pyatt G, Round JI (eds) Social accounting matrices. A basis for planning. The World Bank, Washington, DC

Torvik R (2009) Why do some resource-abundant countries succeed while others do not? Oxford Rev Econ Policy 25(2):241-256

United Nations, Commission of the European Communities, International Monetary Fund, Organisation for Economic Cooperation and Development, World Bank (1993) System of national accounts. United Nations/Commission of the European Communities/International Monetary Fund/Organisation for Economic Cooperation and Development/World Bank, New York/ Brussels/Washington, DC/Paris/Washington, DC

Van der Ploeg F (2011) Natural resources: curse or blessing? J Econ Lit 49(2):366-420 